\title{
Human MLH1 status can potentially predict cisplatin sensitivity but not microsatellite instability in head and neck squamous cell carcinoma cells
}

\author{
MAKOTO ADACHI ${ }^{1}$, KEI IJICHI ${ }^{2}$, YASUHISA HASEGAWA ${ }^{3}$, HIDEAKI NAKAMURA $^{4}$, \\ TETSUYA OGAWA $^{5}$ and NOBUTAKE KANEMATSU ${ }^{6}$
}

\begin{abstract}
${ }^{1}$ Department of Oral and Maxillofacial Surgery, Yokohama City University Graduate School of Medicine, Yokohama 236-0004; ${ }^{2}$ Department of Otolaryngology - Head and Neck Surgery, Nagoya City University Graduate School of Medical Sciences, Nagoya 467-8601; ${ }^{3}$ Department of Head and Neck Surgery, Aichi Cancer Center Hospital, Nagoya 464-8681; ${ }^{4}$ Department of the Mechanisms of Aging, National Institute for Longevity Sciences, Obu, Aichi 474-8511; ${ }^{5}$ Department of Otorhinolaryngology, Aichi Medical University, Nagakute, Aichi 480-1195; ${ }^{6}$ Department of Oral and Maxillofacial Surgery, Asahi University Graduate School of Dentistry, Mizuho, Gifu 501-0296, Japan
\end{abstract}

Received August 6, 2009; Accepted October 9, 2009

DOI: 10.3892/etm_00000017

\begin{abstract}
Resistance to platinum-based chemotherapy frequently poses a serious problem in the treatment of head and neck squamous cell carcinoma. In this study, we isolated cisplatin-resistant cells from a head and neck squamous cell carcinoma cell line. The mismatch repair (MMR) system is known as one of the cisplatin-resistant mechanisms. When the expression levels of hMLH1 and hMSH2, a mismatch repair gene and its gene product, were analyzed, the hMLH1 mRNA and protein expression levels were significantly decreased in the cisplatin-resistant cell lines compared with a cisplatinsensitive cell line. In addition, the microsatellite instability (MSI) phenotype was examined for the absence of MMR. Our data support the hypothesis that hMLH1 mRNA and protein expression levels are predictors of cisplatin sensitivity, but MSI was not involved in cisplatin resistance. The status of hMLH1 predicts the sensitivity of head and neck squamous cell carcinoma to platinum-based chemotherapy.
\end{abstract}

\section{Introduction}

Cisplatin is a commonly used drug in head and neck cancer chemotherapy in combination with 5-FU or docetaxel. However, one of the major limitations to its use in the treat-

Correspondence to: Dr Makoto Adachi, Department of Oral and Maxillofacial Surgery, Yokohama City University Graduate School of Medicine, 3-9 Fukuura, Kanazawa-ku, Yokohama Kanagawa 236-0004, Japan

E-mail: amakoto@yokohama-cu.ac.jp

Key words: head and neck cancer, cisplatin, Mismatch Repair System, hMLH1, microsatellite instability ment of head and neck cancer is natural or acquired resistance to cisplatin (1). The mechanism of resistance to cisplatin is unclear, but several hypotheses have been suggested in previous reports. Resistance to cisplatin is generally multifactorial and has been shown to be the result of reduced drug accumulation, inactivation by thiol-containing species, increased repair/tolerance of platinum-DNA adducts, and alterations in proteins involved in apoptosis $(2,3)$.

It is generally accepted that the futile attempt to repair cisplatin-induced DNA damage may finally result in the triggering of apoptosis (4). The mismatch repair (MMR) system, one of the signal transduction pathways, is involved in inducing apoptosis. Many studies have demonstrated that the loss of MMR in cisplatin resistance is associated with microsatellite instability (MSI) and reduced apoptosis (5). Cells in which the MMR system has been inactivated display an MSI phenotype identified in tumors of several different origins, both heredity and sporadic (6). Microsatellite sequences are tandem repeat sequences of 1-4 nucleotide units, and more than tens of thousands of different microsatellite sequences are distributed throughout human chromosomes. MSI characterizes the mutator phenotype and is the hallmark of MMR deficiency (7).

In this study, cisplatin-resistant UM-SCC $23 \mathrm{C} / \mathrm{R}$ and UM-SCC 81B cells were isolated from the head and neck squamous cell carcinoma UM-SCC 23 cell line. In cisplatinresistant cells, hMLH1 gene and protein expression levels were decreased in the cisplatin-resistant cell lines. The MSI phenotype was absent in all the cell lines. Our data support the hypothesis that hMLH1 is an important predictor of cisplatin sensitivity, while MSI was not involved in cisplatin sensitivity.

\section{Materials and methods}

Cells and cell culture. The UM-SCC 23 and UM-SCC 81B cells (head and neck squamous cell carcinoma cell lines) were 
kindly donated by Dr Thomas E. Carey, Laboratory of Head and Neck Cancer Biology at the University of Michigan. The cells were maintained in Dulbecco's modified Eagle's medium (DMEM; Sigma, MO, USA) supplemented with $10 \%$ fetal bovine serum (FBS; Invitrogen, CA, USA) in a humidified atmosphere of $5 \% \mathrm{CO}_{2}$ at $37^{\circ} \mathrm{C}$.

Isolation of cisplatin-resistant cells. UM-SCC 23 cells $\left(10 \times 10^{6}\right)$ were inoculated into a $10-\mathrm{cm}$ dish and cultured for $24 \mathrm{~h}$ in DMEM with $10 \%$ FBS. Cells were then treated with cisplatin (Nihonkayaku, Tokyo, Japan) at a concentration of $0.5 \mathrm{mg} / \mathrm{ml}$ for $24 \mathrm{~h}$, then cultured in DMEM without cisplatin until returning to stable growth. The concentration of cisplatin treatment was stepwisely increased from 1.0, 2.0, 3.0, 4.0 to $5.0 \mathrm{mg} / \mathrm{ml}$.

Colony formation assay for cisplatin sensitivity. The appropriate number of cells were inoculated in a $6-\mathrm{cm}$ dish, and treated with each concentration of cisplatin for $24 \mathrm{~h}$. The cells were washed twice with PBS, and the culture medium was exchanged for a fresh one. Seven to fourteen days after inoculation, colonies were stained with $0.05 \%$ crystal violet. Colonies of $\geq 50$ cells were scored as originating from a single clonogenic cell.

Analysis of hMLH1 and hMSH2 mRNA expression. Expression of hMLH1 and hMSH2 mRNA in each cell line was determined by real-time RT-PCR. Total RNA was extracted with TRIzol reagent (Invitrogen) from the cell lines, and first cDNA strand synthesis, performed with ThermoScript ${ }^{\mathrm{TM}}$ (Invitrogen) for the detection of hMLH1 and hMSH2 mRNA, was amplified under the following conditions: $10 \mathrm{~min}$ at $95^{\circ} \mathrm{C}$ and 40 cycles of $5 \mathrm{sec}$ at $95^{\circ} \mathrm{C}, 20 \mathrm{sec}$ at $60^{\circ} \mathrm{C}$ and 40 sec at $72^{\circ} \mathrm{C}$. The LightCycler System (Roche Diagnostics, Sandhoferstrase, Mannheim, Germany) with SYBR Green PCR Core Reagents (PE Biosystems, Werrinton, UK) was used. Expression levels of hMLH1 and hMSH6 mRNA for each sample were determined by standardizing with the expression level of $\beta$-actin.

Western blot analysis. To observe the expression of hMLH1 and $\mathrm{hMSH} 2$, proteins were extracted with RIPA solution ( $1 \%$ NP-40, sodium deoxycholate and $0.05 \%$ SDS in PBS). Total protein $(10 \mu \mathrm{g})$ was loaded onto a $10 \%$ SDS gel and blotted onto a nitrocellulose membrane after electrophoresis. The primary mouse polyclonal anti-hMLH1 (Pharmingen, CA, USA), polyclonal anti-hMSH2 (Serotec Ltd., Oxford, UK) and polyclonal anti- $\beta$-actin (Abcam, Cambridge, UK) were used in 1:200, 1:200 and 1:10,000 dilutions, respectively.

The secondary antibodies were peroxidase-conjugated anti-mouse $\operatorname{IgG}$ used in a 1:10,000 dilution. Immunoreactive proteins were detected using enhanced chemiluminescence (ECL; Amersham Pharmacia Biotech Inc., NJ, USA).

DNA preparation and microsatellite analysis. Approximately 50-100 cells were seeded onto a $10-\mathrm{cm}$ dish and cultured at $37^{\circ} \mathrm{C}$ in $5 \% \mathrm{CO}_{2}$ for 7 days, and the colony was prepared. Using small cloning cylinders, each single clone was isolated, inoculated into a well of a 48-well plate, and grown to confluence. DNA samples for PCR amplification were prepared by

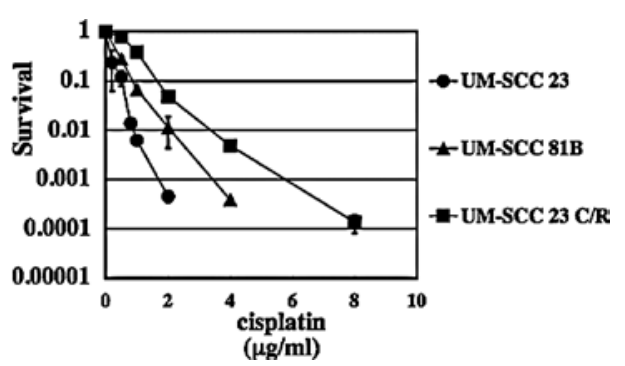

Figure 1. Sensitivities of head and neck squamous cell carcinoma and resistant cell lines to cisplatin. UM-SCC 23, UM-SCC 81B and UM-SCC $23 \mathrm{C} / \mathrm{R}$ cells were treated with cisplatin for $24 \mathrm{~h}$, and the cytotoxicity was analyzed using a colony-formation assay. Each data point is the mean of three independent experiments. Vertical bars represent standard deviations.

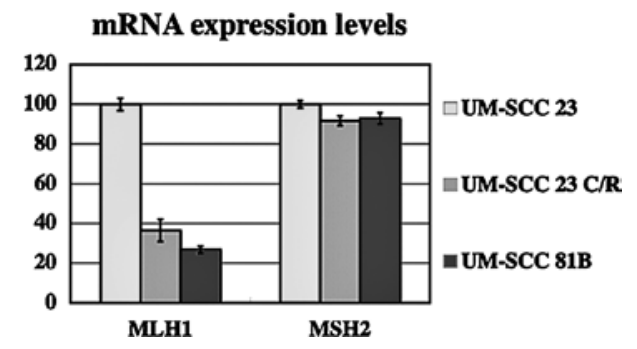

Figure 2. mRNA expression levels of hMLH1 and hMSH2. UM-SCC 23, UM-SCC $81 \mathrm{~B}$ and UM-SCC $23 \mathrm{C} / \mathrm{R}$ cells were analyzed using real-time RT-PCR. Each data point is the mean of three independent experiments. Vertical bars represent standard deviations.

treating the cells with cytolytic solutions $(10 \mathrm{mM}$ Tris- $\mathrm{HCl}$ of $100 \mu \mathrm{l}, 1 \mathrm{mM}$ EDTA, $5 \mu \mathrm{g} / \mathrm{ml}$ Proteinase $\mathrm{K}$ ) for $2 \mathrm{~h}$ at $65^{\circ} \mathrm{C}$ and $15 \mathrm{~min}$ at $95^{\circ} \mathrm{C}$. Extracted DNA was amplified on microsatellite loci D9S171 and D13S175 by PCR using microsatellite primer (ABI PRISM ${ }^{\circledast}$ Linkage Mapping Sets, version 2.5; Applied Biosystems, CA, USA). The reaction was conducted under the following conditions: $12 \mathrm{~min}$ at $95^{\circ} \mathrm{C}, 10$ cycles of $15 \mathrm{sec}$ at $95^{\circ} \mathrm{C}, 15 \mathrm{sec}$ at $55^{\circ} \mathrm{C}, 15 \mathrm{sec}$ at $72^{\circ} \mathrm{C}$ and 20 cycles of $15 \mathrm{sec}$ at $89^{\circ} \mathrm{C}, 15 \mathrm{sec}$ at $55^{\circ} \mathrm{C}, 15 \mathrm{sec}$ at $72^{\circ} \mathrm{C}$. Microsatellite analysis was performed with the ABI PRISM 310 Genetic Analyzer (Applied Biosystems).

\section{Results}

Cisplatin sensitivity of each cell line. The cisplatin sensitivity of the UM-SCC 23 cells, and of the UM-SCC 81B and UM-SCC $23 \mathrm{C} / \mathrm{R}$ cells isolated from the UM-SCC 23 cell line by colony formation assay, was analyzed. The results are shown in Fig. 1. UM-SCC 81B cells, the intrinisic cisplatinresistant cell line for cisplatin, were $\sim 2$-fold more resistant than UM-SCC 23 cells. UM-SCC 23 C/R cells were $\sim 3.5$-fold more resistant to cisplatin than UM-SCC 23 cells.

hMLH1 and hMSH2 mRNA expression levels. Expression of hMLH1 and hMSH2 mRNA in UM-SCC 23 and UM-SCC 23 $\mathrm{C} / \mathrm{R}$ cells was analyzed by real-time RT-PCR. Expression levels of hMLH1 mRNA in UM-SCC 81B and UM-SCC 23 $\mathrm{C} / \mathrm{R}$ cells were decreased $\sim 60 \%$ as compared with UM-SCC 23 cells. A difference in hMSH2 mRNA expression level was not found among the three cell lines (Fig. 2). 


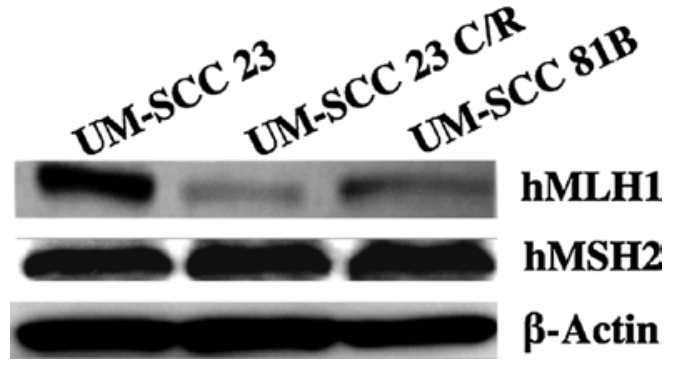

Figure 3. Expression levels of hMLH1 and hMSH2 mismatch repair proteins. UM-SCC 23, UM-SCC 81B and UM-SCC 23 C/R cells were examined by Western blot analysis.

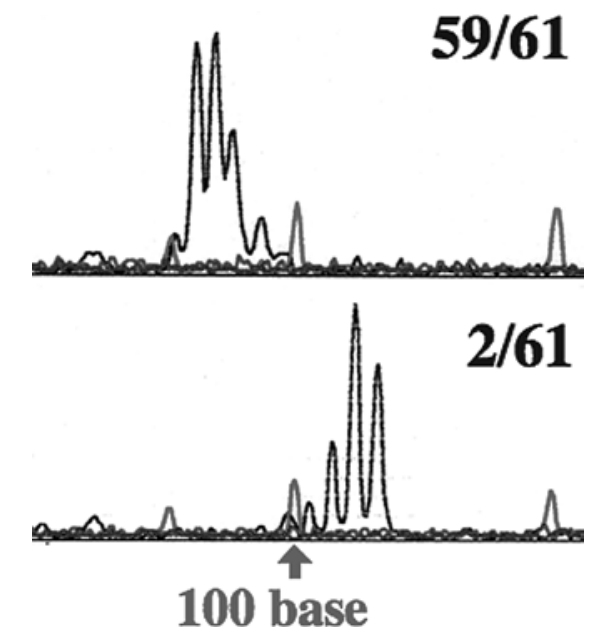

Figure 4. Changes in the microsatellite sequence. Microsatellite sequence changes were detected with Gene Scan. Results in D9S171 for UM-SCC 81B are shown. The upper column shows results noted in 59 of 61 samples, the lower column shows microsatellite sequence changes in 2 of 61 samples. The red lines indicate base size marker and the black lines indicate the samples. The arrow shows 100 bases.

hMLH1 and hMSH2 protein expression level. hMLH1 and hMSH2 mismatch repair proteins were analyzed by Western blot analysis. The hMLH1 protein expression level was decreased to a greater extent in the UM-SCC $23 \mathrm{C} / \mathrm{R}$ than in the UM-SCC 23 cells. The hMLH1 expression level was further decreased in the UM-SCC 81B cells. hMSH2 was examined using the same method, but no change was found among the three cell lines (Fig. 3).

Microsatellite instability. Microsatellite instability was analyzed with Gene Scan. A change in the microsatellite was found in 1 of 55 samples in D9S171 for the UM-SCC 23 cells. Sixty-six samples of UM-SCC $23 \mathrm{C} / \mathrm{R}$ cells were analyzed, but changes in the microsatellite were not observed. The microsatellite changes were found in 2 samples each in D9S171 and D13S175 among 61 samples for UM-SCC 81B cells (Fig. 4; Table I).

\section{Discussion}

The MMR system plays an important role in the control of genomic instability in cells. In order to ensure genomic
Table I. The ratio of the microsatellite change in each cell line.

\begin{tabular}{lcc}
\hline & \multicolumn{2}{c}{ Change } \\
\cline { 2 - 3 } & D9S171 & D13S175 \\
\hline UM-SCC 23 & $1 / 55(1.81 \%)$ & $0 / 55(0.00 \%)$ \\
UM-SCC 23 C/R & $0 / 66(0.00 \%)$ & $0 / 66(0.00 \%)$ \\
UM-SCC 81B & $2 / 61(3.03 \%)$ & $2 / 61(3.03 \%)$ \\
\hline
\end{tabular}

stability, it is necessary that the repair of DNA occurs prior to DNA replication (8). Before repair is initiated, the damage to DNA must be recognized by specific proteins. Indeed, a number of DNA damage recognition proteins have been identified, but studies to define their involvement in cisplatinresistant tumor cells have largely been confined to the MMR complex (9). MMR serves a critical purpose in maintaining the integrity of the genome through the repair of DNA mismatch lesions, but does not actually repair cisplatin adducts. One proposed theory is that MMR attempts to repair the lesion, but in failing to do so activates the apoptotic signal (10).

In this study, no difference was observed in hMSH2 mRNA and protein expression levels among the three cell lines. However, hMLH1 mRNA and protein expression levels were significantly decreased in the cisplatin-resistant cells. The MMR system involves at least five proteins (hMLH1, hMSH2, hMSH3, hMSH6 and hPMS2) and functions as an ATP-dependent repair process that corrects misincorporated nucleotides. hMSH2/hMSH6 heterodimers directly bind, as the first mismatch recognizing complex, to GpG intrastrand adducts of cisplatin, and hMLH1/hPMS2 heterodimers are subsequently recruited to play an important role as the hMSH2/hMSH6/hMLH1/hPMS2 complex, and induce the stabilization and pro-apoptotic activation of p73 (11). This process requires both the MMR system and the c-Abl kinase. Previous studies have shown a decreased hMLH1 expression level or a defect caused by methylation of the promoter domain of hMLH1 in cisplatin-resistant cells (12). It is thought that the expression level of hMLH1 involved in apoptotic induction is decreased through recognition of the cisplatin adduct in the process in which cells acquire cisplatin resistance. Therefore, the cisplatin-DNA-adduct is recognized by hMSH2; however, the decrease of the apoptosis signal pathway mediated by the mismatch repair system decreases hMLH1 expression levels, resulting in the development of cisplatin resistance (13). In light of this observation regarding cisplatin sensitivity, hMLH1 mRNA and gene product expression levels may be predictors of natural and acquired cisplatin resistance.

Analysis of the microsatellite sequence in UM-SCC 23, UM-SCC 81B and UM-SCC $23 \mathrm{C} / \mathrm{R}$ cells indicated changes in the microsatellite in 2 samples each of D9S171 and D13S175 among 61 samples in UM-SCC 81B cells, a natural cisplatinresistant cell line. The frequency of microsatellite changes was much lower than in other reports of MSI. In addition, a microsatellite change was not found in UM-SCC $23 \mathrm{C} / \mathrm{R}$ cells established as cisplatin-resistant cells. MSI was hardly evident in the three cell lines. The absence of MSI in sporadic colon 
cancer can be a predictive marker of sensitivity for the first post-operative adjuvant chemotherapy (14), and sensitivity of cisplatin-based chemotherapy is not associated with MSI in cervical cancer $(15,16)$.

In conclusion, since hMLH1 mRNA and protein expression levels were decreased in the UM-SCC 81B and UM-SCC 23 $\mathrm{C} / \mathrm{R}$ natural and acquired cisplatin-resistant cell lines, cisplatin adduct recognition was deduced to be involved in the acquisition of cisplatin resistance. Therefore, hMLH1 gene and gene product expression levels are effective predictors of the sensitivity to cisplatin in head and neck cancer chemotherapy. In addition, MSI was not present in conjunction with decreased hMLH1 expression levels; therefore, cisplatin-based chemotherapy is not associated with the frequency of MSI.

\section{References}

1. Choong $\mathrm{N}$ and Vokes E: Expanding role of the medical oncologist in the management of head and neck cancer. CA Cancer J Clin 58: 32-53, 2008.

2. Wozniak $\mathrm{K}$ and Blasiak $\mathrm{J}$ : Recognition and repair of DNA-cisplatin adducts. Acta Biochim Pol 49: 583-596, 2002.

3. Siddik ZH: Cisplatin: mode of cytotoxic action and molecular basis of resistance. Oncogene 22: 7265-7279, 2003.

4. Yang Z, Faustino PJ, Andrews PA, Monastra R, Rasmussen AA, Ellison CD and Cullen KJ: Decreased cisplatin/DNA adduct formation is associated with cisplatin resistance in human head and neck cancer cell lines. Cancer Chemother Pharmacol 46: 255-262, 2000 .

5. Papouli E, Cejka P and Jiricny J: Dependence of the cytotoxicity of DNA-damaging agents on the mismatch repair status of human cells. Cancer Res 64: 3391-3394, 2004.

6. Colella G, Marchini S, D'Incalci M, Brown R and Broggini M: Mismatch repair deficiency is associated with resistance to DNA minor groove alkylating agents. Br J Cancer 80: 338-343, 1999.
7. Geisler JP, Goodheart MJ, Sood AK, Holmes RJ, HattermanZogg MA and Buller RE: Mismatch repair gene expression defects contribute to microsatellite instability in ovarian carcinoma. Cancer 98: 2199-2206, 2003.

8. Ishizaki K, Nishizawa K, Kato T, Kitao H, Han ZB, Hirayama J, Suzuki F, Cannon TF, Kamigaichi S, Tawarayama Y, Masukawa M, Shimazu T and Ikenaga M: Genetic changes induced in human cells in Space Shuttle experiment (STS-95). Aviat Space Environ Med 72: 794-798, 2001.

9. Manic S, Gatti L, Carenini N, Fumagalli G, Zunino F and Perego P: Mechanisms controlling sensitivity to platinum complexes: role of p53 and DNA mismatch repair. Curr Cancer Drug Targets 3: 21-29, 2003.

10. Pani E, Stojic L, El-Shemerly M, Jiricny J and Ferrari S: Mismatch repair status and the response of human cells to cisplatin. Cell Cycle 15: 1796-1802, 2007.

11. Shimodaira H, Yoshioka-Yamashita A, Kolodner RD and Wang JY: Interaction of mismatch repair protein PMS2 and the p53-related transcription factor $\mathrm{p} 73$ in apoptosis response to cisplatin. Proc Natl Acad Sci USA 100: 2420-2425, 2003.

12. Cejka P, Stojic L, Mojas N, Russell AM, Heinimann K, Cannavó E, di Pietro M, Marra G and Jiricny J: Methylationinduced $\mathrm{G}(2) / \mathrm{M}$ arrest requires a full complement of the mismatch repair protein hMLH1. EMBO J 22: 2245-2254, 2003.

13. Stojic L, Brun R and Jiricny J: Mismatch repair and DNA damage signaling. DNA Repair 3: 1091-1101, 2004.

14. Ribic CM, Sargent DJ, Moore MJ, Thibodeau SN, French AJ, Goldberg RM, Hamilton SR, Laurent-Puig P, Gryfe R, Shepherd LE, Tu D, Redston $M$ and Gallinger S: Tumor microsatellite-instability status as a predictor of benefit from fluorouracil-based adjuvant chemotherapy for colon cancer. N Engl J Med 349: 247-257, 2003.

15. Helleman J, van Staveren IL, Dinjens WN, van Kuijk PF, Ritstier K, Ewing PC, van der Burg ME, Stoter G and Berns EM: Mismatch repair and treatment resistance in ovarian cancer. BMC Cancer 31: 201, 2006.

16. Magnowska M, Surowiak P, Nowak-Markwitz E, Michalak M, Magnowski P, Rokita W, Kedzia H, Zabel M and Spaczyński M: Analysis of hMLH1 and hMSH2 expression in cisplatin-treated ovarian cancer patients. Ginekol Pol 79: 826-834, 2008. 